\title{
Development of Procedures for Determining the Optimal Placement of Symmetration Devices for Electrical Supply Systems 0.4 kV with Motor-Actuated Load
}

Viktoria V. Romanova, Sergey V. Khromov and Ivan F. Suvorov* Transbaikal State University 30 Aleksandro-Zavodskaya Str., Chita, 672039, Russia

In this paper, we consider the development of methods for determining the optimal location of symmetrization devices for $0.4 \mathrm{kV}$ power supply systems with motor-actuated load. The methodology includes the features of electric consumers and their geographical location. The practice procedures for application of the existing power supply system the Taptugary village, the Mogochinsk region, the Trans-Baikal Territory was given as an example. The practical significance for the developed application procedures was justified. The optimal solution of balancing problem based on economical parameters was obtained.

Keywords: power supply system, voltage asymmetry, asynchronous motor, power losses.

Citation: Romanova V.V., Khromov S.V., Suvorov I.F. Development of procedures for determining the optimal placement of symmetration devices for electrical supply systems $0.4 \mathrm{kV}$ with motor-actuated load, J. Sib. Fed. Univ. Eng. technol., 2018, 11(5), 528-535. DOI: 10.17516/1999-494X-0051.

(C) Siberian Federal University. All rights reserved

* Corresponding author E-mail address: sergeixrom@inbox.ru, romanova181@mail.ru 


\title{
Разработка методики определения
}

\section{оптимального размещения устройств симметрирования \\ для систем электроснабжения 0,4 кB \\ с электродвигательной нагрузкой}

\author{
В.В. Романова, С.В. Хромов, И.Ф. Суворов \\ Забайкальский государственный университет \\ Россия, 672039, Чита, ул. Александро-Заводская, 30
}

\begin{abstract}
Рассматриваются вопросы разработки методики определения оптимального размещения устройств симметрирования для систем электроснабжения $0,4 \kappa B$ с электродвигательной нагрузкой. В методику заложены особенности электропотребителей и их географическое расположение. Приведен пример применения методики для существующей системь электроснабжения с. Таптугары Могочинского района Забайкальского края. Дано обоснование практической значимости применения разработанной методики. Получено оптимальное решение вопроса симметрирования исходя из экономических показателей.
\end{abstract}

Ключевые слова: система электроснабжения, несимметрия напряжений, асинхронный двигатель, потери мощности.

\section{Introduction}

At present the power quality (PQ) problems are paid particular attention. Under current conditions, the power quality indices (PQI) such as voltage asymmetry and non-sinusoidality have become indispensable factors, which reduce the performance of the power supply systems themselves significantly and their connected consumers accordingly.

According to the research of the basic power quality indices in $0.4,6$ and $35 \mathrm{kV}$ network nodes of the Trans-Baikal Territory power system it was found that deviation of the basic PQI such as voltage asymmetry and non-sinusoidality is a permanent factor during operation of the Trans-Baikal power system networks. In a number of cases the asymmetry level exceeds the GOST 32144 - 2013 [1] rated value [2] (by $2-3$ times).

Due to unsatisfactory condition of PQ in the Trans-Baikal power system distribution networks, a great number of electric equipment failures at the consumers' facilities is observed. According to damage rate analysis of asynchronous motors (AM) at the Trans-Baikal Territory enterprises during 2015 - 2016, a large number of motor damage cases was registered in different sections of the Mogochinsk region. The emergencies are mainly associated with the voltage asymmetry of the supply mains.

The electric equipment reliability and performance is directly related to PQ in the distribution networks. For steady-state operation of the power-consuming units it is necessary to carry out a number of actions directed at PQ improvement and at voltage asymmetry removal, in particular.

Within this work framework, one of possible actions for PQ improvement, due to introduction of balancing devices into power supply system (PSS) at the designing stage is proposed. 
This work scope is development and approbation for determining the optimal location of symmetrization devices for $0.4 \mathrm{kV}$ power supply systems with motor-actuated load (using the example of the Trans-Baikal Territory).

\section{Task setting}

In accordance with the set goal the task on development of the power supply system calculation algorithm subject to using the balancing devices and their installation locations was implemented, based on which the procedure will be built. The diagram for calculation algorithm of the power supply system subject to using the balancing devices and their installation locations is given in Fig. 1.

Based on the experimental research data of the basic PQI, the information on the value of power loss in the elements of the power supply system under study, and, in addition, relying upon customers' allowable operating modes, it is possible to select the parameters of the balancing devices and determine the optimal location of these devices in the power supply system. Thus, the calculation of the value for supplementary power losses due to voltage asymmetry will enable to define the economic feasibility for carrying out particular actions for asymmetry removal, and besides, to specify the optimal application and location of these devices.

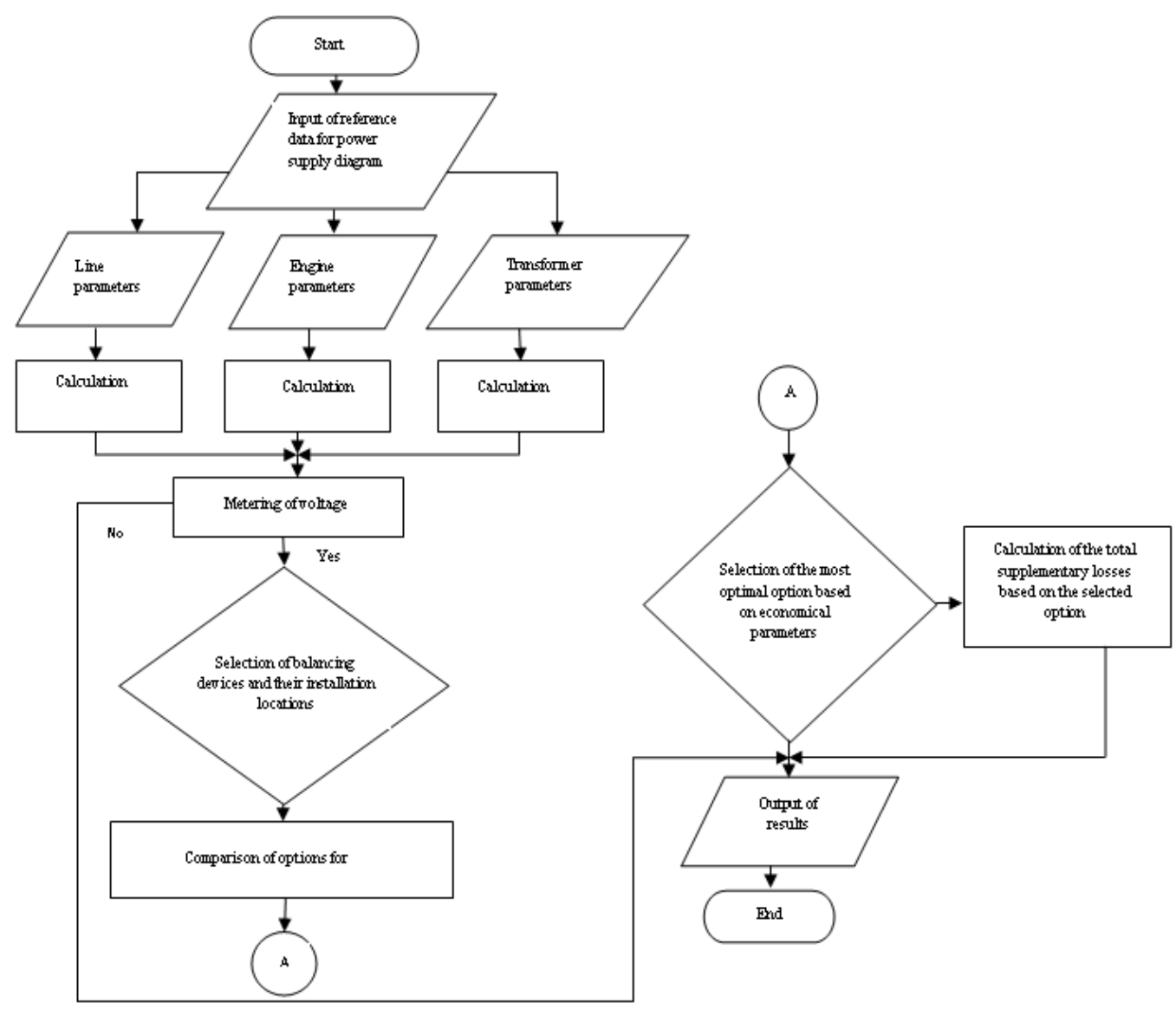

Fig. 1. Block diagram for calculation algorithm of the power supply system subject to using the balancing devices and their installation locations 


\section{Research results and their discussion}

The developed procedure is a matter of interest during development of projects for power supply systems for regions with available non-linear loads.

The main criterion for the procedure application consists in excess of the voltage asymmetry coefficient statistical value $\left(K_{2 U}\right)$ in negative-phase sequence for this PSS over the allowable value $K_{2 U}$ for AM (Table 1) installed in the same power supply system. The required $\mathrm{k}_{2 \mathrm{U}}$ value is selected based on the customer's allowable operating mode. The values of the allowable value $K_{2 U}$ for AM are taken from the research results [3].

The procedure can be implemented in the following sequence:

1) let us determine the losses for symmetrical operating modes in the main elements of the power supply system.

Calculation of supplementary power losses is made by formulas given in [4].

The losses in the power transmission lines are determined based on the expression:

$$
\Delta P_{\mathrm{PTL}}=3 I_{1}^{2} r_{\mathrm{ph}}
$$

where $I_{1}-$ symmetrical operating mode current (positive-phase sequence current); $r_{\mathrm{ph}}-$ phase conductor resistance.

Real-power $\Delta P^{\prime}$ and reactive $\Delta Q^{\prime}$ power losses for double-wound transformers are determined based on the expression:

$$
\begin{aligned}
& \Delta P^{\prime}=\frac{\Delta P_{k}}{n}\left(\frac{S}{S_{r t}}\right)^{2}, \\
& \Delta Q^{\prime}=\frac{U_{k}}{100 \cdot n} \cdot \frac{S^{2}}{S_{r t}},
\end{aligned}
$$

where $P_{k}, U_{k}, S_{r t}$ - nameplate data of individual transformer; $S$ - substation full load (total of individual transformer loads); $n$ - number of one-type transformers in the substation, parallel operating.

2) let us determine the losses for asymmetrical operating modes in the main elements of the power supply system.

The available amplitude and angular asymmetry during estimation of increase of supplementary losses as compared to symmetrical operating mode can be accounted using the coefficient $K_{\text {as: }}$ :

$$
K_{a s}=1+K_{2 I}^{2}+K_{0 I}^{2} \cdot\left(1+3 \cdot \frac{R_{N}}{R_{P H}}\right),
$$

where $K_{2 I}, K_{0 I}$ - coefficients for asymmetry of negative-phase and zero-phase sequence currents. Based on the results of processing the statistical data for basic PQI in $0.4 \mathrm{kV}$ network nodes of the Mogochinsk region, the Trans-Baikal Territory, we take on the values equal to $K_{2 I}=5 \%, K_{0 I}=4.6 \%, K_{2 U}=4.95 \%$; $R_{\mathrm{N}}, R_{\mathrm{PH}}-$ resistances of the neutral and phase conductors.

Table 1. Table of allowable values $K_{2 U}$

\begin{tabular}{|c|c|c|}
\hline Motor model & Motor power, $\mathrm{P}_{\mathrm{L}}, \mathrm{kW}$ & Allowable value $K_{2 U}, \%$ \\
\hline 4A132S4Y3 & 7.5 & 1.8 \\
\hline AI132M4 & 11 & 1.26 \\
\hline
\end{tabular}


Accordingly, taking into account (3), the expression (1) will be as follows:

$$
\Delta P_{\text {SUPL.PTL }}=\Delta P_{P T L} K_{a s}
$$

The supplementary losses of the real-power in the asynchronous motor are determined based on the expression:

$$
\Delta P_{\text {SUPL.AM }}=2,41 k_{A M} K_{2 U}^{2} P_{L},
$$

where $k_{A M}$ - the coefficient, accounting the particular motor parameters (rated power, stator copper losses, starting current-to-rated current ratio); $K_{2 U}$ - coefficient of voltage asymmetry in negativephase sequence; $P_{L}$ - rated motor real power.

The coefficient $k_{A M}$ value for industrial overall load is advised to take on equal to 1.85 .

During long-sustained asymmetrical operating mode, due to the flow of negative-phase sequence currents, the supplementary power losses occur in the power transformers, which can be determined by the following formula:

$$
\Delta P_{S U P L T R}=K_{2 U}^{2}\left(\Delta P_{I M}+\frac{\Delta P_{S C}}{u_{S C}^{2}}\right)
$$

where $K_{2 U}$ - the voltage asymmetry coefficient in negative-phase sequence; $\Delta P_{\mathrm{IM}}-$ losses during idle mode; $\Delta P_{\mathrm{SC}}-$ losses during short-circuit mode; $U_{\mathrm{SC}}-$ short-circuit voltage.

3) let us proceed to taking the special measures for removal of the voltage asymmetry and determination of the optimal application and location of these devices.

Let us calculate the optimal location and selection of the balancing devices. The following subtasks shall be solved for this purpose:

a) detect the motor, which is most sensitive to voltage asymmetry out of all motors present in the power supply system,

b) determine the losses for asymmetric operating mode in the main elements of the power supply system with installed balancing device in the central node of the diagram. Calculate the payback period for installation of the balancing device.

Calculation of the payback period for installation of the balancing device can be determined by the following formula:

$$
P P=\frac{S}{((\Delta \text { Psupl. } w+\Delta Q \text { supl. } w)-(\Delta \text { Psupl. }+\Delta Q \text { supl. })) * \mathrm{C}},
$$

where $P P$ - the payback period; $S$ - the total cost of the installed balancing devices; $\Delta$ Psupl. $w+\Delta Q$ supl. $w$ - supplementary losses without the balancing devices; $\Delta P$ supl. $+\Delta Q$ supl. supplementary losses with the balancing device; $C$ - the cost of the electric power.

c) determine the losses for asymmetric operating mode in the main elements of the power supply system with installed balancing device in each motor individually. Calculate the payback period for installation of the balancing device,

d) based on calculation results analysis select the most optimal option,

e) carry out installation of the balancing device in the power supply system.

To implement the procedure let us consider the power supply system section of the Taptugary village, the Mogochinsk region, the Trans-Baikal Territory. 
The following reference information was used for execution of this work:

1) the results of processing the statistical data for basic PQI in $0.4 \mathrm{kV}$ network nodes of the Mogochinsk region, the Trans-Baikal Territory,

2) the configuration of the power supply system section of the Taptugary village, the electric power consumers' characteristics.

The power supply system, on which the procedure was approved, is given in Fig. 2. The power supply system section diagram consists of:

1) line 1 - wired with AS-25 (steel-aluminium conductor), the line length is 350 metres, feeds 7 private residence houses with furnace heating,

2) line 2 - cabled with GRSh $3 * 50+1 * 35$ (cable with flexible core, rubber cover and poly amide silk isolation), the line length is 50 metres, feeds the two-storeyed residence house, the primary school, the kindergarten, the administration building and the library,

3) line 3 - cabled with AVVshv 4*50 (cable with aluminium core, PVC jacket, with protective layer in the form of pressed out hose), the line length is 70 metres, feeds the boiler house with two boilers and motors: the model $4 \mathrm{~A} 132 \mathrm{~S} 4 \mathrm{Y} 3 \mathrm{P}_{\mathrm{L}}=7.5 \mathrm{~kW}, 2$ pcs., the smoke exhaust fan $\mathrm{P}_{\mathrm{L}}=3 \mathrm{~kW}$, the draught fan $\mathrm{P}_{\mathrm{L}}=1.4 \mathrm{~kW}$,

4) line 4 - wired with SIP $4 * 25$ (self-supporting insulated conductor), the line length is 150 metres, feeds two ban mills with motors model AI132M4 $\mathrm{P}_{\mathrm{L}}=11 \mathrm{~kW}, 2$ pcs.

Calculation of the power supply wiring diagram was made using the widely spread computer program Microsoft Office Excel. Main calculation results are summarized in Table 3. The cost indicators are taken from the sources $[5,6]$.

Thus, following the calculation results we obtained the value of power losses in the main elements of the power supply system for the symmetrical operating mode, the asymmetrical operating mode without installation of the balancing device and the asymmetrical operating mode with installed balancing device. Based on the data of results let us determine the number, power and the location for installation of the balancing device.

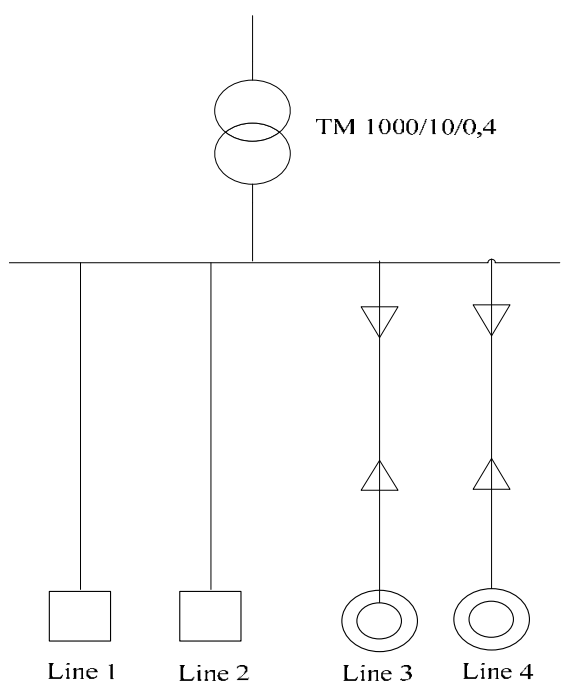

Fig. 2. Power supply system section diagram of the Taptugary village 
Table 2. Reference data of the village Taptugary network section

\begin{tabular}{|c|c|c|c|c|c|}
\hline Parameter & Line 1 & Line 2 & Line 3 & Line 4 & TS \\
\hline Power, kVA & 30.4 & 49.4 & 20.9 & 25 & 100 \\
\hline Current, $\mathrm{A}$ & 80 & 130 & 55 & 65.7 & 330.7 \\
\hline
\end{tabular}

Table 3. Calculation of payback period for installation of the balancing device based on supplementary power losses

\begin{tabular}{|l|c|}
\hline \multicolumn{1}{|c|}{ Losses } & $\Delta \mathrm{P}+\Delta \mathrm{Q}, \mathrm{kVA}$ \\
\hline 1) During symmetrical operating mode & $17.0+\mathrm{j} 16.0$ \\
\hline 2) Supplementary losses during asymmetrical operating mode & $8.4+\mathrm{j} 0.2$ \\
\hline without balancing device & $2.5+\mathrm{j} 0.2$ \\
\hline during installation of the individual balancing device in the motor - option 1 & $2.7+\mathrm{j} 0.2$ \\
\hline during installation of the common balancing device in all motors - option 2 & - \\
\hline 3) Cost of balancing devices, thu. rbs. & 39 \\
\hline Balancing device $\mathrm{P}_{\mathrm{L}}=9 \mathrm{~kW}$ & 45 \\
\hline Balancing device $\mathrm{P}_{\mathrm{L}}=11 \mathrm{~kW}$ & 126 \\
\hline Balancing device $\mathrm{P}_{\mathrm{L}}=45 \mathrm{~kW}$ & 5 \\
\hline Cost $\mathrm{kW}$ *hour, rbs & 168 \\
\hline Total cost of BD $($ balancing device), option 1, thu. rbs. & 126 \\
\hline Total cost of BD, option 2, thu. rbs. & 8.28 \\
\hline Payback period, option 1, months & 5.95 \\
\hline Payback period, option 2, months & \\
\hline
\end{tabular}

Analysing the data given in Table 3 the conclusion can be made that for considered diagram it is economically viable to install one balancing device with $45 \mathrm{~kW}$ power on the common node of the lines 3,4 , containing the motor-actuated load, but not the individual one on each motor.

Following the results of the procedure implementation we found the necessity for application of the balancing devices for industrial consumers in the diagram under research. We selected the most cost-effective location of the balancing device in PSS.

It is evident that only upon available reliable information about the levels of PQI distortion, about the operating modes of the power consumers it is possible to make up the requirements specification for PSS designing and to select the optimal parameters for the balancing devices.

\section{Conclusion}

The developed procedure is of practical interest for designing of $0.4 \mathrm{kV}$ power supply systems containing the motor-actuated load under voltage asymmetry conditions. The specifics of the electric power consumers' operating modes and their geographical location are built in the procedure.

Application of the procedure in PSS with available motor-actuated load will allow increase the operating reliability and efficiency of the asynchronous motors. 
The proposed procedure will be the basis for implementation of the task for creation of the software complex allowing to make quick and accurate calculation of the power losses, to determine the economical feasibility of provision special measures for removal of the voltage asymmetry, for determination of optimal application and location of the balancing devices.

The work was executed within the framework of FSBEI HPE Trans-Baikal State University Council for Research and Innovative Activities Scientific Grant No. 247 - GR of 30/01/2018 implementation.

\section{References}

[1] ГОСТ 32144 - 2013. Электрическая энергия. Совместимость технических средств электромагнитная. Нормы качества электрической энергии в системах электроснабжения общего назначения. М.: Стандартинформ, 2014. 19 с. [GOST 32144 - 2013. Electric power Electromagnetic compatibility of technical equipment. Electric energy quality standards in the general-purpose power supply systems, Moscow, Standartinform, 2014, 19 p. (in Russian)].

[2] Романова В.В., Хромов С.В. Состояние качества электрической энергии в распределительных сетях Забайкальского края. Электроэнергетика байкальского региона: проблемы и перспективы: материалы Всероссийской научно-практической конференции, 2016, 20 - 25 [Romanova V.V., Khromov S.V. Electric energy quality status in the Trans-Baikal Territory distribution networks. Electric power in Trans-Baikal region: problems and prospects: All-Russia scientific and practical conference materials, 2016, 20 - 25 (in Russian)].

[3] Романова В.В., Хромов С.В., Суворов И.Ф. Новый подход к нормированию коэффициента несимметрии напряжений по обратной последовательности $\mathrm{K}_{2 \mathrm{U}}$ для узлов нагрузок систем электроснабжения с асинхронными двигателями. Современные технологии. Системный анализ. Моделирование, 2017, 1 (53), 209 - 214 [Romanova V.V., Khromov S.V., Suvorov I.F. New approach to normalizing of the voltage asymmetry coefficient in negative-phase sequence $\mathrm{K}_{2 \mathrm{u}}$ for nodes of loads in the power supply systems with asynchronous motors. Modern technologies. System analysis. Simulation, 2017, 1 (53), 209 - 214 (in Russian)].

[4] Дед А.В., Паршукова А.В., Халитов Н.А. Оценка дополнительных потерь мощности от несимметрии напряжений и токов в элементах систем электроснабжения. Международный журнал прикладных и фундаментальных исследований, 2015, 10, 421 - 425 [Ded A.V., Parshukova A.V., Khalitov N.A. Estimation of supplementary power losses due to voltage asymmetry and currents in the power supply system elements. International Journal of Basic and Applied Research, 2015, 10, 421 - 425 (in Russian)].

[5] Трехфазные стабилизаторы напряжения 380 вольт [Электронный ресурс]. Режим доступа: http://voltmarket.ru/catalog/trekhfaznye_stabilizatory [Three-phase voltage stabilizers 380 Volts [Electronic resource]. Access: http://voltmarket.ru/catalog/trekhfaznye_ stabilizatory

[6] Энерго 24. Тарифы на электроэнергию для Читы и Забайкальского края с 1 июля 2016 года [Электронный ресурс]. Режим доступа: https://energo-24.ru/authors/energo-24/11017. html [Energo-24. Electricity tariffs for Chita and Trans-Baikal Territory from July 1, 2016 [Electronic resource] Access: https://energo-24.ru/authors/energo-24/11017.html 